\title{
Fungsi bahasa dan makna pragmatik dalam media sosial untuk memerangi Covid-19: Kajian etnopragmatik
}

\author{
Pranowo Pranowo ${ }^{a} 1^{*}$, Diani Febriasarib, 2 \\ a Pendidikan Bahasa dan Sastra Indonesia, FKIP, USD \\ b Pendidikan Bahasa dan Sastra Indonesia, FKIP, USD \\ ${ }^{1}$ prof.pranowo2@gmail.com*; diani_febriasari@yahoo.com; \\ *korespondensi penulis
}

\begin{tabular}{ll}
\hline Informasi artikel & \\
\hline Sejarah artikel: & \\
Diterima & : Juli 2020 \\
Revisi & : Oktober 2020 \\
Dipublikasikan & : Oktober 2020 \\
\hline
\end{tabular}

\section{Kata kunci:}

Fungsi bahasa

Makna pragmatik

Media sosial

Etnopragmatik

\begin{abstract}
ABSTRAK
Artikel ini membahas fungsi bahasa dan makna pragmatik di media sosial untuk memerangi Covid-19. Acuan teori yang digunakan adalah etnopragmatik. Kajian etnografi pada dasarnya mengkaji bahasa dari aspek budaya. Aspek budaya mencakup pengetahuan, perilaku, dan artefak. Sementara itu, pragmatik merupakan kajian penggunaan bahasa atas dasar konteks. Penelitian ini menggunakan sumber data dari instagram, facebook, WA, dan email. Data penelitiannya berupa penggunaan bahasa yang terdapat di media sosial dalam sumber data. Data dari Instagram dan Facebook diunduh dari internet, sementara data dari email dikumpulkan melalui arahan peneliti dengan panduan dalam instrument. Teknik pengumpulan data dilakukan melalui baca dan catat. Teknik analisis data secara konkret dilakukan melalui identifikasi data, klasifikasi data, interpretasi data, dan pelaporan dalam bentuk artikel jurnal. Temuan hasil penelitian subfungsi bahasa meliputi menyuruh, mengajak atau mempengaruhi, menyindir, memotivasi dan mengkritik, dan mengucapkan terima kasih. Sementara itu, makna pragmatik yang digunakan dalam media sosial mencakup menasihati secara tidak langsung, membujuk, mengingatkan secara tidak langsung, menyindir secara halus, mengajak, mengeluh, dan memberi saran.
\end{abstract}

Key word:

Language function

Pragmatic meaning

Social media

Ethnopragmatics

\begin{abstract}
This article discusses the function of language and pragmatic meaning in social media to combat Covid-I9. Theoretical references used are ethnopragmatics. Ethnographic studies basically examine language from a cultural aspect. Cultural aspects include knowledge, behavior, and artifacts. Meanwhile, pragmatics is a study of language use on the basis of context. This research uses data sources from Instagram, Facebook, WA, and email. Research data in the form of language use in social media above. Data from Instagram and Facebook are downloaded from the internet, while data from email is collected through the direction of researchers with guidance on the instrument. Data collection techniques are done through reading and taking notes. Concrete data analysis techniques are carried out through data identification, data classification, data interpretation, and reporting in the form of journal articles. The findings of research on language subfunctions include asking, inviting or influencing, being sarcastic, motivating and criticizing, and saying thank you. Meanwhile, the pragmatic meaning used in social media includes indirectly advising, persuading, indirectly reminding, subtly insinuating, inviting, complaining, and give advice.
\end{abstract}

\section{Copyright (C) 2018 Universitas Ahmad Dahlan. All Right Reserved}

\section{Pendahuluan}

Atas dasar survei untuk melihat perbandingan kepemilikan smartphone dan telepon seluler biasa di antara orang dewasa, terungkap posisi Indonesia berada di urutan ke-24 dari 27 negara. Seluruh orang dewasa yang memiliki HP di Indonesia mencakup
42\% memiliki smarphoe, 28\% memiliki HP biasa, dan 29\% tidak memiliki HP (Alfarizi, 2020). Jika dihitung dari jumlah penduduk Indonesia yang berada di kisaran 27I juta, berarti orang dewasa pemilik HP smartphone sebanyak II3,820 juta orang. Dari jumlah sebanyak itu, mereka adalah orang-orang aktif pengguna HP untuk berbagai 
program aplikasi untuk berbagai keperluan. Dengan demikian, jika setiap orang dewasa menggunakan media sosial, betapa besarnya interaksi antarmanusia di Indonesia melalui media sosial.

Realita di lapangan, aplikasi You Tube, Facebook, Twitter, Instagram, WA dan lain-lain ternyata dikuasai oleh sebagian besar masyarakat Indonesia yang memiliki HP. Oleh karena itu, langkah selanjutnya yang perlu dipikirkan adalah bagaimana cara mengendalikan Covid-I9 dengan memanfaatkan hasil penelitian dengan cara menyajikan dalam bentuk yang lebih sederhana sehingga mudah dipahami dan dapat tersebar secara massif kepada masyarakat melalui berbagai aplikasi media sosial.

Dilihat dari sisi positifnya, media sosial menjadi media untuk saling berbagi sehingga setiap orang seperti memiliki media sediri. Melalui media sosial, setiap orang dapat saling berbagi gagasan, berkolaborasi untuk menciptakan kreasi, berpikir, menemukan teman berdiskusi, menemukan pasangan, dan membangun sebuah komunitas. Intinya, menggunakan media sosial menjadikan seseorang sebagai diri sendiri. Selain kecepatan informasi yang bisa diakses dalam hitungan detik, media sosial dapat menjadi media untuk aktualisasi diri dan bahkan dapat menciptakan personal branding. Semua itu hanya dapat dilakukan menggunakan bahasa (Nurrizka, 2016).

Bahasa dalam media sosial adalah bahasa yang digunakan untuk berkomunkasi melalui berbagai program aplikasi daring, seperti instagram, whatsApp, facebook, twitter, email, you tube, dll. Jika pemilik HP smartphone memanfaatkan media sosial dengan content ajakan untuk memerangi Covid-19, sebenarnya warga negara Indonesia sangat mudah dijangkau untuk diajak mengendalikan wabah Covid-I9.

Para ahli bahasa, meskipun tidak mengetahui masalah medis termasuk Covid-I9 dapat memberi sumbangan pemikiran untuk ikut andil memberantas Covid-I9 di Indonesia. Covid-I9 pada awalnya tersebar di daerah Wuhan, salah satu wilayah di Cina. Virus tersebut menyebar ke mana-mana karena mobilitas orang bepergian dari dan ke Wuhan. Akibatnya, semua orang di muka bumi banyak yang terinfeksi virus corona. Informasi seperti itu diketahui melalui bahasa yang disebarkan oleh media komunikasi maupun media informasi (Buana, 2020).

Data pemakaian bahasa dalam media sosial memiliki beberapa fungsi antara lain untuk memberi informasi, mengingatkan, menyindir, dan menasihati. Struktur bahasa yang digunakan adalah sederhana, tidak baku, banyak singkatan, banyak terjadi alih kode dan campur kode. Makna kata yang digunakan dalam media sosial adalah makna kata yang memiliki daya sentuh, daya bujuk (persuasi), daya pikat, bercanda, dll.

Artikel ini menggunakan pendekatan etnopragmatik. Etnopragmatik adalah pendekatan interdisipliner antara etnografi dan pragmatik. Kajian etnografi pada dasarnya adalah kajian bahasa atas dasar teori kebudayaan. Kebudayaan merupakan pandangan hidup dari sekelompok orang dalam bentuk perilaku, kepercayaan, nilai, dan simbol-simbol yang mereka terima tanpa sadar yang semuanya diwariskan melalui proses komunikasi dari satu generasi ke generasi berikutnya (Blount, 20II). Lebih lanjut, Blount mengklasifikasikan kebudayaan menjadi tiga macam, yaitu pengetahuan, perilaku, dan artefak. Pertama, pengetahuan pada hakikatnya adalah gagasan ideal yang berbentuk kumpulan ide, gagasan, nilai, norma, peraturan yang sifatnya abstrak. Jika masyarakat menyatakan gagasan mereka itu dalam bentuk tulisan, lokasi dari kebudayaan ideal itu berada dalam karangan dan buku-buku hasil karya warga masyarakat tersebut. Kedua, aktivitas (perilaku) adalah wujud kebudayaan sebagai suatu tindakan berpola dari manusia dalam masyarakat. Wujud ini sering pula disebut dengan sistem sosial yang berupa aktivitas manusia yang saling berinteraksi, mengadakan kontak, serta bergaul dengan manusia lainnya menurut pola-pola tertentu yang berdasarkan adat tata kelakuan. Sifatnya konkret, terjadi dalam kehidupan sehari-hari, dan dapat diamati dan didokumentasikan. Ketiga, artefak adalah wujud kebudayaan fisik yang berupa hasil dari aktivitas, perbuatan, dan karya semua manusia dalam masyarakat berupa benda-benda atau hal-hal yang dapat diraba, dilihat, dan didokumentasikan. Sifatnya paling konkret di antara ketiga wujud kebudayaan.

Sementara itu, Pragmatik merupakan kajian penggunaan bahasa atas dasar konteks pemakaiannya (Porayska-pomsta, Mellish, Pain, Eugenio, \& Moore, 2000); (Yusny, 2013). Konteks yang dimaksud adalah segala situasi yang ada di luar tuturan, baik konteks verbal maupun nonverbal dalam pemakaian bahasa. Dalam suatu tuturan, konteks kemudian dibingkai atau disusun dalam bentuk skema agar tuturan dapat ditafsirkan maknanya. Skema dipandang sebagai pengetahuan konvensional, seperti struktur-struktur yang ada dalam ingatan kita dan diaktifkan dalam kondisi tertentu dalam interpretasi terhadap sesuatu yang dialami. Pada tingkat yang sangat jelas, kita memiliki skema untuk kegiatan verbal yang biasa dalam hidup kita, misalnya, skema makanan, skema keluarga, skema kantor, dan sebagainya (Kaburise, 2012). 
Kajian pragmatik yang mencolok atas dasar data penelitian adalah aspek tindak tutur. Aspek tindak tutur yang dimaksud adalah tindakan berbahasa yang melibatkan aspek lokusi, ilokusi, dan perlokusi (Searle, 1962; Austin, 1962a). Tindak lokusi adalah tindak berbahasa yang berupa serentetan bunyi yang membentuk kata, frasa, kalimat, paragraf, atau wacana yang memiliki makna sama persis seperti strukturnya. Misalnya, "Anak2 nasibnya piye pak nek sekolah bukak?? Ora gampang nyuruh anak kecil pake masker pak. ora gampang anak kecil cuci tangan sing bener pakkk...." (Aldillafr). Konteks tuturannya adalah " Rentetan tuturan itu membentuk kalimat yang maknanya sama seperti bunyinya, yaitu mempertanyakan nasib anakanak kecil yang tidak mudah untuk memakai masker dan rajin cuci tangan. Namun, di balik tuturan itu, ilokusinya tentu bukan pertanyaan tetapi minta solusi terbaik jika sekolah dibuka, apa yang harus dilakukan untuk melindungi anak-anak agar tidak terpapar Covid-I9. Sementara itu, perlokusinya adalah efek yang timbul setelah pendengar membaca tuturan tersebut. Perlokusinya adalah agar pemerintah mampu mengatur agar anak-anak tetap dapat sekolah tetapi terlindungi dari paparan Covid19. Hal-hal seperti itu banyak terjadi dalam data Instagram yang disampakan masyarakat kepada Gubernur Ganjar Pranowo.

Di sisi lain, kajian pragmatik adalah kajian fungsi bahasa yaitu fungsi yang digunakan untuk menyampaikan pesan dalam berkomunikasi. (Halliday, 1973 dalam Santosa, 2008) mengklasifikaskan fungsi bahasa menjadi 7 fungsi, yaitu (I) fungsi representasional, (2) fungsi interaksional, (3) fungsi personal, (4) fungsi regulatori, (5) fungsi heuristik, (6) fungsi instrumental, dan (7) fungsi imajinatif. Hal yang sama juga dilakukan oleh Searle yang mengidentifikasi tindak tutur, meliputi (a) tindak representasional, (b) tindakan direktif, (c) tindakan komisif, (d) tindakan ekspresif, dan (e) tindakan deklaratif (Searle, 1963 dalam Kaburise, 2012).

Fungsi bahasa yang dimaksud adalah penggunaan bahasa untuk berkomunikasi dengan tujuan tertentu. Bahasa dapat digunakan sebagai alat untuk mengekspresikan diri, alat untuk berintegrasi, alat beradaptasi dengan lingkungan sosial, dan sebagai alat untuk kontrol sosial. Masing-masing peran memiliki fungsi sendiri-sendiri sesuai dengan tujuan komunikasi. Sebagai alat komunikasi, bahasa dimaksudkan untuk menyampaikan pesan penutur agar dapat dipahami oleh mitra tutur, apa pun wujud pesan itu (Ita Suryani, 20I4). Sebagai alat ekspresi diri, bahasa dapat digunakan untuk mengungkapkan apa pun yang dirasakan baik untuk diri sendiri maupun untuk orang lain (misalnya, mengeluh, menggerendeng, dsb.). Bahasa bahasa sebagai bagian dari kehidupan sosial mampu mengintegrasikan diri dengan anggota masyarakat lain agar tidak terpisahkan dengan lingkungan sosialnya. Hal ini penting karena dengan bahasa, penutur dapat beradaptasi dengan lingkungan sosialnya agar dapat diterima sebagai bagian dari masyarakatnya. Bahkan, bahasa dapat berfungsi sebagai alat kontrol sosial dalam arti bahwa bahasa selalu mampu memberi pertimbangan terhadap apa yang diucapkan agar tidak terlepas dari pranata sosial yang berlaku dalam masyarakat (Watie, 2016).

Dari berbagai fungsi bahasa, di era digital seperti sekarang ini, bahasa mampu berfungsi lebih dari fungsi-fungsi konvensional yang selama ini dijalaninya. Ketika bahasa digunakan untuk menyampaikan fungsi komunikatif melalui media cetak (koran, jurnal, buku, majalah, dsb) atau media elektronik konvensional seperti radio dan televisi, pesan bahasa cenderung satu arah. Jika pesan itu direspon oleh pembaca atau pendengar, biasanya terjadi jauh dari waktu terjadinya peristiwa tutur. Hal ini sangat berbeda dengan media sosial di era digital. Pada saat komunikasi terjadi, pada saat itu pula respon dari pembaca atau pendengar langsung dapat terjadi. Bahkan, respon yang diberikan dapat berkembang ke mana-mana ke seluruh pembaca atau pendengar.

Atas dasar uraian di atas, tujuan penelitian artikel ini adalah (a) mendeskripsikan fungsi bahasa yang sering digunakan untuk menyadarkan masyarakat agar tidak terpapar Covid-I9, dan (b) mendeskripsikan makna pragmatik yang digunakan dalam media sosial agar masyarakat tidak terpapar Covid-19. Atas dasar survei untuk melihat perbandingan kepemilikan smartphone dan telepon seluler biasa di antara orang dewasa, terungkap posisi Indonesia berada di urutan ke-24 dari 27 negara. Seluruh orang dewasa yang memiliki HP di Indonesia mencakup 42\% memiliki smarphoe, 28\% memiliki HP biasa, dan 29\% tidak memiliki HP (Alfarizi, 2020). Jika dihitung dari jumlah penduduk Indonesia yang berada di kisaran 27I juta, berarti orang dewasa pemilik HP smartphone sebanyak II3,820 juta orang. Dari jumlah sebanyak itu, mereka adalah orang-orang aktif pengguna HP untuk berbagai program aplikasi untuk berbagai keperluan. Dengan demikian, jika setiap orang dewasa menggunakan media sosial, betapa besarnya interaksi antarmanusia di Indonesia melalui media sosial.

Realita di lapangan, aplikasi You Tube, Facebook, Twitter, Instagram, WA dan lain-lain ternyata dikuasai oleh sebagian besar masyarakat Indonesia yang memiliki HP. Oleh karena itu, 
langkah selanjutnya yang perlu dipikirkan adalah bagaimana cara mengendalikan Covid-19 dengan memanfaatkan hasil penelitian dengan cara menyajikan dalam bentuk yang lebih sederhana sehingga mudah dipahami dan dapat tersebar secara massif kepada masyarakat melalui berbagai aplikasi media sosial.

Dilihat dari sisi positifnya, media sosial menjadi media untuk saling berbagi sehingga setiap orang seperti memiliki media sediri. Melalui media sosial, setiap orang dapat saling berbagi gagasan, berkolaborasi untuk menciptakan kreasi, berpikir, menemukan teman berdiskusi, menemukan pasangan, dan membangun sebuah komunitas. Intinya, menggunakan media sosial menjadikan seseorang sebagai diri sendiri. Selain kecepatan informasi yang bisa diakses dalam hitungan detik, media sosial dapat menjadi media untuk aktualisasi diri dan bahkan dapat menciptakan personal branding. Semua itu hanya dapat dilakukan menggunakan bahasa (Nurrizka, 2016).

Bahasa dalam media sosial adalah bahasa yang digunakan untuk berkomunkasi melalui berbagai program aplikasi daring, seperti instagram, whatsApp, facebook, twitter, email, you tube, dll. Jika pemilik HP smartphone memanfaatkan media sosial dengan content ajakan untuk memerangi Covid-19, sebenarnya warga negara Indonesia sangat mudah dijangkau untuk diajak mengendalikan wabah Covid-19.

Para ahli bahasa, meskipun tidak mengetahui masalah medis termasuk Covid-I9 dapat memberi sumbangan pemikiran untuk ikut andil memberantas Covid-I9 di Indonesia. Covid-19 pada awalnya tersebar di daerah Wuhan, salah satu wilayah di Cina. Virus tersebut menyebar ke mana-mana karena mobilitas orang bepergian dari dan ke Wuhan. Akibatnya, semua orang di muka bumi banyak yang terinfeksi virus corona. Informasi seperti itu diketahui melalui bahasa yang disebarkan oleh media komunikasi maupun media informasi (Buana, 2020).

Data pemakaian bahasa dalam media sosial memiliki beberapa fungsi antara lain untuk memberi informasi, mengingatkan, menyindir, dan menasihati. Struktur bahasa yang digunakan adalah sederhana, tidak baku, banyak singkatan, banyak terjadi alih kode dan campur kode. Makna kata yang digunakan dalam media sosial adalah makna kata yang memiliki daya sentuh, daya bujuk (persuasi), daya pikat, bercanda, dll.

Artikel ini menggunakan pendekatan etnopragmatik. Etnopragmatik adalah pendekatan interdisipliner antara etnografi dan pragmatik. Kajian etnografi pada dasarnya adalah kajian bahasa atas dasar teori kebudayaan. Kebudayaan merupakan pandangan hidup dari sekelompok orang dalam bentuk perilaku, kepercayaan, nilai, dan simbolsimbol yang mereka terima tanpa sadar yang semuanya diwariskan melalui proses komunikasi dari satu generasi ke generasi berikutnya (Blount, 20II). Lebih lanjut, Blount mengklasifikasikan kebudayaan menjadi tiga macam, yaitu pengetahuan, perilaku, dan artefak. Pertama, pengetahuan pada hakikatnya adalah gagasan ideal yang berbentuk kumpulan ide, gagasan, nilai, norma, peraturan yang sifatnya abstrak. Jika masyarakat menyatakan gagasan mereka itu dalam bentuk tulisan, lokasi dari kebudayaan ideal itu berada dalam karangan dan buku-buku hasil karya warga masyarakat tersebut. Kedua, aktivitas (perilaku) adalah wujud kebudayaan sebagai suatu tindakan berpola dari manusia dalam masyarakat. Wujud ini sering pula disebut dengan sistem sosial yang berupa aktivitas manusia yang saling berinteraksi, mengadakan kontak, serta bergaul dengan manusia lainnya menurut pola-pola tertentu yang berdasarkan adat tata kelakuan. Sifatnya konkret, terjadi dalam kehidupan sehari-hari, dan dapat diamati dan didokumentasikan. Ketiga, artefak adalah wujud kebudayaan fisik yang berupa hasil dari aktivitas, perbuatan, dan karya semua manusia dalam masyarakat berupa benda-benda atau hal-hal yang dapat diraba, dilihat, dan didokumentasikan. Sifatnya paling konkret di antara ketiga wujud kebudayaan.

Sementara itu, Pragmatik merupakan kajian penggunaan bahasa atas dasar konteks pemakaiannya (Porayska-pomsta, Mellish, Pain, Eugenio, \& Moore, 2000); (Yusny, 2013). Konteks yang dimaksud adalah segala situasi yang ada di luar tuturan, baik konteks verbal maupun nonverbal dalam pemakaian bahasa. Dalam suatu tuturan, konteks kemudian dibingkai atau disusun dalam bentuk skema agar tuturan dapat ditafsirkan maknanya. Skema dipandang sebagai pengetahuan konvensional, seperti struktur-struktur yang ada dalam ingatan kita dan diaktifkan dalam kondisi tertentu dalam interpretasi terhadap sesuatu yang dialami. Pada tingkat yang sangat jelas, kita memiliki skema untuk kegiatan verbal yang biasa dalam hidup kita, misalnya, skema makanan, skema keluarga, skema kantor, dan sebagainya (Kaburise, 2012).

Kajian pragmatik yang mencolok atas dasar data penelitian adalah aspek tindak tutur. Aspek tindak tutur yang dimaksud adalah tindakan berbahasa yang melibatkan aspek lokusi, ilokusi, dan perlokusi (Searle, 1962; Austin, 1962a). Tindak lokusi adalah tindak berbahasa yang berupa serentetan bunyi yang membentuk kata, frasa, kalimat, paragraf, atau wacana yang memiliki makna sama persis seperti strukturnya. Misalnya, "Anak2 nasibnya piye pak nek sekolah bukak?? Ora gampang 
nyuruh anak kecil pake masker pak.. ora gampang anak kecil cuci tangan sing bener pakkk...." (Aldillafr). Konteks tuturannya adalah "Rentetan tuturan itu membentuk kalimat yang maknanya sama seperti bunyinya, yaitu mempertanyakan nasib anakanak kecil yang tidak mudah untuk memakai masker dan rajin cuci tangan. Namun, di balik tuturan itu, ilokusinya tentu bukan pertanyaan tetapi minta solusi terbaik jika sekolah dibuka, apa yang harus dilakukan untuk melindungi anak-anak agar tidak terpapar Covid-19. Sementara itu, perlokusinya adalah efek yang timbul setelah pendengar membaca tuturan tersebut. Perlokusinya adalah agar pemerintah mampu mengatur agar anak-anak tetap dapat sekolah tetapi terlindungi dari paparan Covid19. Hal-hal seperti itu banyak terjadi dalam data Instagram yang disampakan masyarakat kepada Gubernur Ganjar Pranowo.

Di sisi lain, kajian pragmatik adalah kajian fungsi bahasa yaitu fungsi yang digunakan untuk menyampaikan pesan dalam berkomunikasi. (Halliday, 1973 dalam Santosa, 2008) mengklasifikaskan fungsi bahasa menjadi 7 fungsi, yaitu (I) fungsi representasional, (2) fungsi interaksional, (3) fungsi personal, (4) fungsi regulatori, (5) fungsi heuristik, (6) fungsi instrumental, dan (7) fungsi imajinatif. Hal yang sama juga dilakukan oleh Searle yang mengidentifikasi tindak tutur, meliputi (a) tindak representasional, (b) tindakan direktif, (c) tindakan komisif, (d) tindakan ekspresif, dan (e) tindakan deklaratif (Searle, 1963 dalam Kaburise, 2012).

Fungsi bahasa yang dimaksud adalah penggunaan bahasa untuk berkomunikasi dengan tujuan tertentu. Bahasa dapat digunakan sebagai alat untuk mengekspresikan diri, alat untuk berintegrasi, alat beradaptasi dengan lingkungan sosial, dan sebagai alat untuk kontrol sosial. Masing-masing peran memiliki fungsi sendiri-sendiri sesuai dengan tujuan komunikasi. Sebagai alat komunikasi, bahasa dimaksudkan untuk menyampaikan pesan penutur agar dapat dipahami oleh mitra tutur, apa pun wujud pesan itu (Ita Suryani, 20I4). Sebagai alat ekspresi diri, bahasa dapat digunakan untuk mengungkapkan apa pun yang dirasakan baik untuk diri sendiri maupun untuk orang lain (misalnya, mengeluh, menggerendeng, dsb.). Bahasa bahasa sebagai bagian dari kehidupan sosial mampu mengintegrasikan diri dengan anggota masyarakat lain agar tidak terpisahkan dengan lingkungan sosialnya. Hal ini penting karena dengan bahasa, penutur dapat beradaptasi dengan lingkungan sosialnya agar dapat diterima sebagai bagian dari masyarakatnya. Bahkan, bahasa dapat berfungsi sebagai alat kontrol sosial dalam arti bahwa bahasa selalu mampu memberi pertimbangan terhadap apa yang diucapkan agar tidak terlepas dari pranata sosial yang berlaku dalam masyarakat (Watie, 2016).

Dari berbagai fungsi bahasa, di era digital seperti sekarang ini, bahasa mampu berfungsi lebih dari fungsi-fungsi konvensional yang selama ini dijalaninya. Ketika bahasa digunakan untuk menyampaikan fungsi komunikatif melalui media cetak (koran, jurnal, buku, majalah, dsb) atau media elektronik konvensional seperti radio dan televisi, pesan bahasa cenderung satu arah. Jika pesan itu direspon oleh pembaca atau pendengar, biasanya terjadi jauh dari waktu terjadinya peristiwa tutur. Hal ini sangat berbeda dengan media sosial di era digital. Pada saat komunikasi terjadi, pada saat itu pula respon dari pembaca atau pendengar langsung dapat terjadi. Bahkan, respon yang diberikan dapat berkembang ke mana-mana ke seluruh pembaca atau pendengar.

Atas dasar uraian di atas, tujuan penelitian artikel ini adalah (a) mendeskripsikan fungsi bahasa yang sering digunakan untuk menyadarkan masyarakat agar tidak terpapar Covid-19, dan (b) mendeskripsikan makna pragmatik yang digunakan dalam media sosial agar masyarakat tidak terpapar Covid-I9.

\section{Metode}

Penelitian ini menggunakan acuan teori Etnopragmatik. Etnopragmatik merupakan kajian interdisipliner antara kajian etnografi dan pragmatik. Kajian etnografi adalah kajian bahasa dari sudut pandang kebudayaan dari sisi pengetahuan, perilaku, dan artifak. Kajian etnografi dari sisi pengetahuan pada hakikatnya lebih menekankan pada aspek pengetahua seseorng menenai bahasanya (terutama kaidah bahasa yang berlaku pada bahasa itu). Kajian mengenai perilaku bahasa pada hakkatnya bagaimana seseorang menggunakan bahasa untuk berkomunikasi melalui tindak tutur. Tindak tutur mencakup lokusi, ilokusi, dan perlokusi. Kajian pragmatik adalah kajian penggunaan bahasa atas dasar konteks. Karena banyak sekali fenomena kajian pragmatik, dalam penelitian ini dibatasi pada aspek fungsi bahasa dan tindak tutur saja. Semua teori itu digunakan untuk melihat pemakaian bahasa di media sosial dalam masyarakat.

Sumber data penelitian adalah beberapa aplikasi media sosial di instagram, facebook, dan email. Data penelitian adalah tuturan yang ditulis dalam berbagai aplikasi media sosial yang berkaitan dengan masalah Covid-19. Data dikumpulkan dengan cara mengunduh pengguna instagram dan facebook, serta mengirimkan instrument melalui email yang dapat dijangkau oleh peneliti. Data tersebut dibatasi pada 
media sosial bulan Maret-April 2020. Teknik analisis data dilakukan dengan langkah-langkah konkret, yaitu (a) mengidentifikasi data yang terdapat dalam sumber data, (b) mengklasifikasi data yang sudah diidentifikasi dari sumber data, dan (c) menginterpretasi hasil klasifikasi untuk menemukan wujud, fungsi, dan makna pragmatik. Tujuan penelitian adalah ingin mendeskripsikan (a) fungsi bahasa yang sering digunakan untuk menyadarkan masyarakat agar tidak terpapar Covid-19, dan (b) makna pragmatik yang terkandung dalam bahasa media sosial agar masyarakat tidak terpapar Covid19. Penelitian ini menggunakan acuan teori Etnopragmatik. Etnopragmatik merupakan kajian interdisipliner antara kajian etnografi dan pragmatik. Kajian etnografi adalah kajian bahasa dari sudut pandang kebudayaan dari sisi pengetahuan, perilaku, dan artifak. Kajian etnografi dari sisi pengetahuan pada hakikatnya lebih menekankan pada aspek pengetahua seseorng menenai bahasanya (terutama kaidah bahasa yang berlaku pada bahasa itu). Kajian mengenai perilaku bahasa pada hakkatnya bagaimana seseorang menggunakan bahasa untuk berkomunikasi melalui tindak tutur. Tindak tutur mencakup lokusi, ilokusi, dan perlokusi. Kajian pragmatik adalah kajian penggunaan bahasa atas dasar konteks. Karena banyak sekali fenomena kajian pragmatik, dalam penelitian ini dibatasi pada aspek fungsi bahasa dan tindak tutur saja. Semua teori itu digunakan untuk melihat pemakaian bahasa di media sosial dalam masyarakat.

Sumber data penelitian adalah beberapa aplikasi media sosial di instagram, facebook, dan email. Data penelitian adalah tuturan yang ditulis dalam berbagai aplikasi media sosial yang berkaitan dengan masalah Covid-19. Data dikumpulkan dengan cara mengunduh pengguna instagram dan facebook, serta mengirimkan instrument melalui email yang dapat dijangkau oleh peneliti. Data tersebut dibatasi pada media sosial bulan Maret-April 2020. Teknik analisis data dilakukan dengan langkah-langkah konkret, yaitu (a) mengidentifikasi data yang terdapat dalam sumber data, (b) mengklasifikasi data yang sudah diidentifikasi dari sumber data, dan (c) menginterpretasi hasil klasifikasi untuk menemukan wujud, fungsi, dan makna pragmatik. Tujuan penelitian adalah ingin mendeskripsikan (a) fungsi bahasa yang sering digunakan untuk menyadarkan masyarakat agar tidak terpapar Covid-19, dan (b) makna pragmatik yang terkandung dalam bahasa media sosial agar masyarakat tidak terpapar Covid19.

\section{Hasil dan pembahasan}

\section{Fungsi Bahasa dalam Komunikasi di Media Sosial}

Atas dasar data yang ditemukan, beberapa fungsi bahasa dalam komunikasi di media sosial pada umumnya merupakan fungsi interpersonal. Fungsi tersebut yang dapat diidentifikasi, antara lain (a) untuk menyuruh, (b) untuk mengajak atau mempengaruhi, (c) untuk menyindir, (d) untuk memotivasi dan mengkritik, (e) untuk mengucapkan terima kasih. Secara sederhana dapat dideskripsikan sebagai berikut.

\section{a) Bahasa untuk menyuruh}

Pemakaian bahasa di media sosial dapat digunakan untuk menyuruh pembaca agar masyarakat tidak terpapar Covid-19, suruhan masyarakat agar dapat terhindar dari paparan Covid19 dapat dilihat dalam data sebagai berikut.

I. Jok ngluyur ae rek!! Iki Suroboyo wes abang nang ndi-ndi! Jok sampe dadi Wuhan. (email ke peneliti)

2. Cuci tanganmu, sebelum corona menjemputmu (emal ke peneliti)

3. Menjaga jarak adalah cara terbaik untuk tetap bersatu (email ke peneliti)

Pemakaian bahasa dalam media sosial dapat menggunakan bahasa apa pun, baik bahasa daerah, bahasa Indonesia, dan bahkan bahasa asing. Yang penting, substansinya adalah memiliki fungsi tertentu dalam komunkasi. Data di atas berfungsi menyuruh orang lain agar tidak terpapar Covid-19. Suruhan tersebut berupa perintah seperti "Jok ngluyur aae rek", "Cuci tanganmu", "menjaga jarak adalah ...".

Ditinjau dari aspek budaya, bahasa merupakan perilaku masyarakat yang diwujudkan dalam bentuk kata, tuturan, atau wacana. Dengan kata lain, tuturan seseorang dapat diwudkan dalam berbagai bentuk. Salah satunya adalah ingin menyuruh seseorang agar melakukan suatu tindakan seperti yang dimaksud penutur. Hal ini sejalan dengan teori pragmatik, bahwa apa yang dimaksud penutur terungkap melalui kata-kata penutur. Meskipun, apa yang dimaksud kadang-kadang tidak sama dengan apa yang dikatakan.

\section{b) Bahasa untuk mengajak/ mempengaruhi}

Bahasa di media sosial dapat juga digunakan untuk mengajak atau mempengaruhi orang lain agar melakukan seperti yang dimaksud oleh penutur. Cara mengajak pun berbeda-beda tergantung siapa penutur dan siapa mitra tuturnya. Jika hubungan penutur dengan mitra tutur memiliki hubungan sangat dekat atau bahkan hubungan kekasih, 
ajakannya dapat dilakukan dengan cara yang mesra. Perhatikan data berikut ini.

4. Sayangi keluarga, tetap di kos saja (email ke peneliti).

5. Sayang Ayo jangan lupa cuci tangan, virus corona hilang, hatipun senang. sayangi keluarga, tetap di kos saja (email ke peneliti).

6. Ayo karantina dirimu sendiri untuk bebas dari virus corona (email ke peneliti)

7. Selamat diri kita, selamatkan sesama kita. Stop keluar rumah agar kita semua selamat.(email ke peneliti)

Dari beberapa data di atas, ajakan dapat dilakukan dengan berbagai cara, seperti "sayangi keluarga...", "Ayo karantina dirimu sendiri ...", "Stop keluar rumah ...". Data tuturan di atas berfungsi mengajak/ mempengaruhi agar pendengar mau menuruti apa yang dimaksud penutur. Dengan demikian, fungsi mengajak atau mempengaruhi sangat besar kemungkinannya akan dituruti oleh pembaca.

\section{c) Bahasa untuk menyindir}

Setiap pengguna media sosial dapat menyampaikan apa pun melalui bahasa. Salah satunya dapat menyindir orang lain atau dapat mentertawakan diri sendiri. Perhatikan data di bawah ini.

\section{IO. - Maaf pak polisi, saya mohon izin keluar dari rumah! (instagraam Kominko) \\ - Lho kamu ini gimana, karena di luar banyak virus Corona yang dapat membunuh kamu. \\ - Maaf pak Polisi, istriku lebih ganas dari pada virus Corona, pak. \\ II. - Saat disuruh shalat di masjid, malah maksa shalat di jalan. Saat dilarang ke masjid (karena darurat) malah nuduh PKI. \\ - Jika sudah terinveksi corona, paling kenceng teriaknya. "Negara harus hadir selamatkan rakyatnya" (Instagram Kominko).}

Atas dasar data IO di atas, nampaknya penutur ingin berimajinasi untuk berkreasi agar dapat menyindir atau mentertawakan diri sendiri dan keluarganya. Nampaknya, karena kejenuhan dikarantina di rumah timbul berbagai persoalan. Bagi mereka yang memiliki rumah besar dan luas, mungkin agak lega karena rasa jenuh, masing-masing dapat membuat aktivitas sendir-sendiri. Namun, bagi mereka yang memiliki rumah kecil dan sempit (baru masuk malah sudah keluar) akan timbul berbagai masalah. Akhirnya, ada yang memaksakan diri untuk keluar dari rumah karena di rumah dan di luar rumah sama-sama ada ancaman.

Begitu halnya dengan data II di atas, sindirannya cukup telak dan bahkan mampu memojokkan orang yang sering berlagak suci tetapi tidak gentelment. Tuturan yang sangat menyindir adalah Jika sudah terinveksi corona, paling kenceng teriaknya. "Negara harus hadir selamatkan rakyatnya”. Warga masyarakat yang memiliki karakter seperti itu ternyata tidak sedikit dan kadang-kadang, mereka bukan rakyat kebanyakan tetapi justru tokoh-tokoh yang dijadikan panutan masyarakat.

Nampaknya budaya Indonesia sangat produktif untuk menghasilkan tuturan untuk menyindir karena budaya Indonesia cenderung sebagai budaya tidak langsung. Dengan tuturan sindiran, komunikasi lebih "nancap" (merasuk) di hati karena tuturan sindiran diungkapkan secara tidak langsung. Begitu juga secara pragmatik, benar apa yang dikatakan oleh para ahli bahwa yang dikatakan belum tentu yang dimaksudkan. Dalam budaya Jawa, sindiran itu sering disebut “nggutuk elor, kena kidul' (memukul utara yang merasa terpukul justru selatan).

\section{d) Bahasa untuk Memotivasi sekaligus Mengkritik}

Media sosial juga dapat digunakan untuk memotivasi masyarakat atau memberi dorongan kepada para petugas medis yang bertugas di lapangan agar tetap bekerja penuh semangat tetapi tidak terpapar virus corona. Perhatikan contoh data di bawah ini.

12. Semangat tenaga medis dlm menangani covid, dan smga tunjangan medis nya segera bs cair dan ditrima ole tenaga medis yg menngani covid, yg suda menunggu berbulan2 dalam pencairan. (Riesha, 2020)

13. Kali ini di Puskesmas. Alhamdulillah temanteman petugas medis di sana sehat dan tetap semangat. Ayo sedulur2, cancut taliwondo, jangan sampai petugas medis berjuang sendiri, kita harus berdampingan dengan mereka dengan TERUS mengenakan masker, jaga jarak, sering cuci tangan dan makan bergizi. CORONA PASTI MINGGAT!. (Pranowo, 2020)

Instagram dalam data 12 memberi dorongan kepada tenaga para medis yang berjuang di garda depan untuk memberantas Covid-I9 agar mereka tidak patah semangat. Namun, di sisi lain sekaligus juga menyentil pemerintah agar tunjangan khusus bagi tenaga medis dan para medis yang ditugaskan untuk menangani Covid-I9 tidak dikesampingkan 
hak-haknya. Begitu pula ajakan Ganjar Pranowo dalam data 13 yang menyemangati petugas medis tetap sehat dan semangat dengan mengajak masyarakat untuk ikut berjuang membantu petugas medis agar tidak berjuang sendiri. Dengan gaya bahasa Pak Ganjar yang begitu gaul sangat mudah dipahami masyarakat dan mendekatkan jarak komunikasi beliau dengan masyarakat. Hal seperti itulah yang terjadi dalam budaya Jawa Tengah. Tuturan I 2 dan 13 di samping memotivasi sekaligus juga memberi sentilan kepada masyarakat agar selalu taat aturan.

\section{(e) Bahasa sebagai ucapan terima kasih}

Media sosial juga dapat dipergunakan untuk mengucapkan terima kasih kepada siapa pun yang berjasa untuk membantu pemerintah. Beberpa data dapat dilihat di bawah ini.

Terkait bantuan ini, Gubernur Jawa Timur Khofifah Indar Parawansa menyampaikan ungkapan terima kasihnya kepada BNPB yang terus mendukung Jatim untuk melakukan percepatanpercepatan dalam penanganan Covid-19. (Pemprov Jawa Timur, 2020)

Gubernur Jawa Timur, Khofifah Indar Parawansa menyampaikan apresiasi yang sangat tinggi kepada seluruh tenaga medis dan paramedis yang bekerja keras luar biasa (Pemprov Jawa Timur, 2020)

Ungkapan terima kasih dari Gubernur Jawa Timur Indar Parawansa kepada BNPB dan para tenaga medis yang telah membantu Pemda Jatim untuk membantu percepatan penanganan Covid-I9 dan ucapan terima kasih kepada tenaga medis dan para medis yang telah bekerja keras untuk menyembuhkan warga masyarakat yang terpapar Covid-19. Namun, sayangnnya hal-hal demikian kurang mendapat respon dari masyarakat.

Memang jika yang memberi ucapan terima kasih seorang pejabat, masyarakat akan menilai sebagai hal yang wajar. Namun, jika ucapan terima kasih itu muncul dari masyarakat, seakan-akan mereka mewakili seluruh warga di komunitasnya sehingga mendapat repon lebih baik dari masyarakat lain.

\section{2) Makna Pragmatik}

Bahasa yang digunakan dalam media sosial memiliki makna pragmatik yang bermacam-macam. Makna pragmatik adalah maksud yang sebenarnya ingin disampaikan oleh penutur. Kadang-kadang, apa yang dikatakan oleh penutur bukan yang dimaksudkan. Begitu juga sebaliknya, yang dimaksudkan justru tidak dikatakan. Beberapa data dapat dilihat di bawah ini.

\section{a) Makna Pragmatik Menasihati}

Penutur kadang-kadang ingin menasihati tetapi kadang-kadang khawatir jika dianggap menggurui atau dianggap sok pintar. Oleh karena itu, tuturan yang dikatakan tidak diungkapkan secara langsug seperti yang dimaksudkan. Perhatikan data berikut ini.

16. Ingat pake masker, jangan cuman ingat dia saja (email ke peneliti).

I7. Tinggal di perantauan lebih baik dari pada mudik membawa penyakit.(email ke peneliti)

I8. Kebersihan sebagian dari iman, covid sebagian dari kuman (email ke peneliti)

19. Dekat di mata jauh di hati kita terinfeksi. Jauh di mata dekat di hati kita aman. (email ke peneliti)

20. Sayangi dirimu, hindari keramaian, putus rantai penularan demi masa depan keluarga mu dan sesama.(email ke peneliti)

21. Sudahkah Anda mencuci tangan hari ini.(email ke peneliti)

Atas dasar data di atas, banyak tuturan yang bermakna pragmatik. Maksudnya menasihati tetapi tidak diungkapkan dalam bentuk nasihat tetapi dalam bentuk lain. Dengan cara demikian, justru pembaca dapat tersentuh hatinya untuk berhati-hati terhadap Covid-I9, misalnya "Ingat pake masker", "tinggal diperantauan lebik baik", "kebersihan sebagian dari iman”, "jauh di mata dekat di hati, kita aman", "sayangi dirimu...", "Sudahkah anda cuci tanngan?”. Memang, makna pragmatik tidak selalu harus berbeda dengan makna semantik. Makna pragmatik pada dasarnya adalah maksud yang ingin disampaikan oleh penutur. Dengan kata lain, makna pragmatik dapat berbeda dan juga dapat sama dengan makna semantiknya asal maksud penutur dapat dipahami oleh pembaca.

\section{b) Makna pragmatik Membujuk}

Tuturan berikut mengandung makna pragmatik membujuk. Namun harus disadari bahwa makna pragmatik dapat juga sama dengan makna semantiknya. Perhatikan contoh di bawah ini.

22. Kamu punya dua pilihan, tetap dirumah, atau tetap di pigura foto (email ke peneliti).

23. Semakin hari harga masker makin mahal tapi tetap saja lebih mahal harga nyawa (email ke peneliti) 
24. Mulailah karantina dirimu sendiri sebelum dikarantina di rumah sakit. (email ke peneliti)

25. Nahan rindu aja bisa, masa gak ketemu sementara gak bisa (email ke peneliti).

26. Tahan rasa rindumu dengan orang tersayang untuk menghindari penyebaran virus corona. (email ke peneliti).

Penutur berusaha membujuk pembaca secara tidak langsung. Data di atas berusaha membujuk pembaca. Kadang-kadang bujukan dapat keras, seperti “.... tetap di rumah, atau tetap di pigura saja”, Namun, ada pula yang halus, seperti , “...lebih mahal harga nyawa", "karantina dirimu, sebelum dikarantina di rumah sakit", atau "tahan rasa rindumu dengan orang tersayang untuk menghindari penyebaran virus corona". dll.

Bujukan yang keras mencerminkan bahwa penutur memiliki perasaan jengkel karena sudah berkali-kali diingatkan merasa tidak digubris. Namun, hal itu seharusnya tidak terjadi di media sosial karena akan sangat terkesan tidak santun. Bujukan akan lebih terasa santun jika diungkapkan dalam bentuk bahasa yang halus.

\section{c) Makna Pragmatik Mengingatkan}

Makna pragmatik mengingatkan dapat diungkapkan dalam berbagai bentuk tuturan, seperti "menyeyogyakaan", "perintah", "bujukan". Perhatikan data berikut ini.

27. Tidak apa-apa bosan dirumah, dari pada bersenang-senang di luar rumah. Jadi jangan keluar rumah untuk stop penyebaran virus corona (email ke peneliti).

28. Cucilah tangan agar kita masih bisa bergandengan (email ke peneliti).

29. Tetap ditumah jika kamu sayang keluarga! (email ke peneliti)

Makna pragmatik juga dapat dipakai untuk mengingatkan, "jangan keluar rumah untuk stop penyebaran virus corona", "Cucilah tangan agar kita masih bisa bergandengan", "Tetap di rumah jika kamu sayang keluarga". Teguran halus bermakna pragmatik seperti itu juah lebh mengena dibandingkan dengan teguran secara langsung. Peringatan secara halus akan mampu menyentuh perasaan mitra tutur dari pada peringatan secara kasar.

\section{d) Makna Pragmatik Menyindir}

Tuturan sindiran dalam budaya Jawa sangat produktif dalam berkomunikasi. Seandainya tuturan selalu dinyatakan secara terbuka, ada kemungkinan hubunan sosial selalu timbul konflik secara terbuka. Oleh karena itu, tidak setiap ada perasaan tidak senang selalu diungkapkan secara terbuka. Alih-alih diungkapkan dalam bentuk tuturan tidak langsung atau dalam bentuk sindiran jauh lebih mengena dari pada tuturan secara langsung. Perhatikan data di bawah ini.

30. Terlalu egois bila kita hanya memikirkan diri sendiri, karena kita juga mempunyai tanggung jawab sosial (email ke peneliti).

3I. Jika sudah terinveksi corona, paling kenceng teriaknya. "Negara harus hadir selamatkan rakyatnya" (email ke peneliti).

Data di atas, jika dilihat dari konteksnya adalah bentuk sindiran. Data tuturan no. 30 adalah sindiran pada orang yang memikirkan diri sendiri. Sementara itu, data tuturan 3I jika dilihat dari konteksnya adalah "ketika orang memaksakan diri untuk tidak bershalat di jalan karena mudah terpapar Covid-I9.

Makna pragmatik pada data 30 sindirannya terasa lebih langsung meskipun masih dapat diterima dengan baik. Pendengar, dengan tuturan seperti itu tidak merasa tersinggung karena dipahami secara logika masih dapat diterima. Namun, sindiran pada data 3I nampaknya lebih "mancap" di hati karena nampaknya penutur juga merasa sudah berkali-kali mengingatkan tetapi tidak digubris.

\section{e) Makna Pragmatik Mengajak}

Melalui tuturan berikut ini, penutur mengajak pendengar agar tidak terpapar Covid-19. Ajakan yang dilakukan sebenarnya biasa saja, seperti yang sudah didengungkan oleh pemerintah. Namun, tidak ada salahnya ajakan itu dilakukan terus-menerus dan berulang-ulang untuk menumbuhkan kebiasaan. Dengan cara demikian diharapkan masyarakat semakin tumbuh kesadarannya agar berubah menjadi perilaku hidup sehat. Perhatikan data di bawah ini

32. Jaga jarak, tapi jangan jauh-jauh, nanti aku kangen (email ke peneliti).

33. "selama covid masih merajalela, selama itulah aku akan terus tetap di rumah saja”" (email ke peneliti).

34. "Jika pulang adalah tempat ternyaman, maka tinggalah untuk tetap aman" (email ke peneliti).

Data di atas bermaksud untuk mengajak pembaca tidak harus menggunakan kata "Ayo" tetapi substansinya memang mengajak, seperti "Jaga jarak", "selama covid masih merajalela, Selama itulah aku akan terus tetap di rumah saja". Begitu juga, "Jika 
pulang adalah tempat ternyaman, maka tinggalah untuk tetap aman”. Dilihat secara semantik, makna tuturan tersebut seperti perintah. Namun, makna pragmatiknya adalah ajakan kepada pendengar untuk tidak pergi ke mana-mana agar tidak terpapar CovidI9.

\section{(f) Makna Pragmatik Mengeluh}

Bahasa dalam media sosial ibarat "keranjang sampah”, tuturan apa pun dapat masuk tanpa ada pemilahan, pemilihan, dan editing. Orang mengeluh pun dapat diungkapkan di media sosial. Perhatikan data berikut ini.

35. Anak2 nasibnya piye pak nek sekolah bukak?? Ora gampang nyuruh anak kecil pake masker pak.. ora gampang anak kecil cuci tangan sing bener pakkk...(Pranowo, 2020)

36. Min gimana web nya hari ini masih eror. Tapi kirim email udah $4 x$ ngga kekirim krn server bermasalah. Terus bagaimana? Kemarin sdh urus lewat web $2 x$ tapi di cek juga ga masuk. Ini udah dipanggil tugas (dkijakarta, 2020).

Media sosial adalah media untuk siapa dan apa saja. Jadi, jika ada yang mengeluh, menyindir, menasihati, bahkaan mengumpat itu memang hak mereka. Namun, semua itu juga harus berani bertanggug jawab atas ucapan dan perbuatannya. Data 35, keluhan seorang Ibu yang memiliki anak kecil yang sudah sekolah meminta jalan keluar bagaimana agar mereka tetap dapat sekolah tetapi tidak terpapar Covid-I9. Sementara itu, data no. 36 merupakan keluhan, karena sudah mengadu berkalikali justru web nya error. Permasalahan seperti ini sering diungkapkan oleh pembaca melalui media sosial.

\section{(g) Makna Pragmatik Saran}

Pemakaian bahasa di media sosial dapat digunakan untuk mengeluh, memberi saran, peringatan dan lain-lain. Hal ini merupakan hak setiap pemakai media sosial. Perhatikan data berikut ini.

37. Kenapa persiapan terus Pak? kan new normal itu hal wajar + wajib. Sebelum ada vaksin harus merubah gaya hidup. Fokus pada satu per satu sektor dulu jangan langsung semua sektor. Contoh Malaysia, mereka sudah membuka sektor perdagangan (mall, pasar) tapi belum membuka sektor pariwisata. Fokus pada lah penting seperti ekonomi. Hanya sekedar saran dan pasti banyak salahnya (Tjahya I3, 2020)

38. New normal, kembali beraktivitas seperti biasa, tetap harus waspada, wajib pakai masker, jaga jarak aman, cuci tangan, selalu jaga kesehatan, semoga semua lekas membaik \#Indonesia bisa. (Nuryanti22, 2020)

39. Melalui bantuan ini, diharapkan pemeriksaan tes swab PCR pada Orang Tanpa Gejala (OTG) juga bisa dilakukan mengingat kontribusi OTG terhadap kasus konfirmasi Covid-I9 di Jatim meningkat hingga 34 persen. (Jatim Pemprov, 2020)

Data no 37 mengharapkan agar new normal segera dilakukan tetapi secara bertahap, tidak semua sektor dibuka semua. Saya kira itu saran baik. Data no. 38 adalah hampir sama dengan data sebelumnya tetapi mengkonkretkan agar new normal tetap memakai masker, jaga jarak, dan selalu cuci tangan. Sementara itu, data no 39 memberi saran agar pemeriksaan tes swab PCR dapat segera dilakukan. Dengan berbagai cara penyampaian, semuanya adalah saran masyarakat kepada pihak-pihak yang berkepentingan. Atas dasar data seperti itu, pengguna media sosial sudah merasa terpuaskan melalui cuitannya.

\section{Diskusi}

Jika dilihat dari sudut pandang etnografi dan pragmatik khsusunya fungsi bahasa dan makna pragmatik, ada beberapa hal dapat didiskusikan. Dari aspek budaya, bahasa yang dipakai dalam media sosial lebih banyak berfungsi sebagai alat penghubung antarwarga, antardaerah, antarbudaya untuk menunjukan jati diri pribadi, alat ekspresi diri, alat untuk menjalin hubungan pertemanan, bahkan untuk saling mengenal lebih jauh latar belakang budaya, daerah asal, dan sebagainya. Dari aspek fungsi bahasa, seperti yang dikemukakan oleh Halliday (dalam Brown et al., 2013) dan (Lukin et al., 20II) fungsi bahasa yang muncul dalam media sosial lebih banyak subfungsinya, yaitu (a) menyuruh, (b) mempengaruhi, (c) menyindir, (d) mengkritik, (e) mengucapkan terima kasih. Dengan demikian, perilaku bahasa secara kultural di media sosial sebenarnya masih sangat terbatas, meskipun pengguna smartphone sudah mencapai lebih dari I 3,820 juta orang atau $42 \%$ dari penduduk Indonesia (Alfarizi, 2020). Dengan demikian, fungsi bahasa di media sosial untuk kepentingan pengendalian Covid-19 masih belum maksimal. Lebih-lebih untuk pengendalian Covid-I9.

Di samping itu, makna pragmatik dalam media sosial lebih banyak berfungsi sebagai sosialisasi SOP (Standard Operational Prosedure) yang telah dirancang pemerintah. Berbagai bentuk sosialisasi yang mengandung makna pragmatik yaitu (a) menasihati secara tidak langsung, (b) 
membujuk, (c) mengingatkan secara tidak langsung, (d) menyindir secara halus, (e) mengajak, (f) mengeluh, dan $(\mathrm{g})$ memberi saran. Hal ini sangat wajar karena fungsi media sosial dalam masyarakat semakin luas dan penggunanya semakin bertambah banyak.

Banyaknya pengguna konten media sosial membuat masyarakat mudah dalam menyampaikan pikiran dan perasaan dalam situasi tertentu sehingga menimbulkan suatu pengaruh yang diharapkan. Hal ini terjadi karena masyarakat bebas berkomunikasi dan prosesnya berlangsung pada konteks sosial, fisik, maupun psikologis. Oleh sebab itu, komunikasi sebagai sarana komunikasi mengandung banyak fungsi, yaitu sebagai alat motivasi, sarana pengendali, sarana penyampai informasi, dan sarana pengungkap emosional (Robbins, 2002: 3I0-3I I).

Dalam media sosial seperti instagram dan facebook, masyarakat dapat memberikan motivasi, informasi, dan mengungkapkan perasaannya pada status atau kolom komentar. Dari fasilitas yang disediakan oleh media sosial tersebut, hubungan antara penulis dan pembaca menjadi resiprokal. Tidak sedikit pembaca yang salah menafsirkan maksud penulis sehingga menimbulkan kontestasi. Oleh sebab itu masyarakat diharapkan dapat memahami ilmu pragmatik. Hal ini terjadi karena pengguna media sosial khususnya instagram dan facebook diharapkan dapat manafsirkan informasi penulis dan pembaca serta dapat menyimpulkan maksud tulisan agar informasi yang diterima sama dengan yang dimaksud oleh penulis.

Bahasa di media sosial biasanya singkat, lucu, inkonvensional strukturnya, berisi bujukan, nasihat, mengajak bercanda, menyindir, mengritik, dll. Oleh karena itu perlu dipahami dan disikapi secara bijaksana bahwa sumbangan ahli bahasa akan berkaitan dengaan fungsi bahasa di media sosial dalam berkomunikasi. Namun jika dicermati secara mendalam, hampir semua informasi dapat sampai kepada pembaca atau pendengar jika disampaikan melalui bahasa. Bentuk penyampaiannya melalui bahasa, sementara substansi yang disampaikan dapat berupa apa saja. Subuah definisi singkat oleh Harold D. Lasswell bahwa cara yang tepat untuk menerangkan suatu tindakan komunikasi ialah menjawab pertanyaan "siapa yang menyampaikan, apa yang disampaikan, melalui saluran apa, kepada siapa dan apa pengaruhnya" (Pertiwi, 2018). Hal demikian sama dengan yang disampaikan oleh ahli pragmatik (Brown, \& Yule, 2013) bahwa dalam berkomunikasi yang penting "bukan hanya apa yang dikatakan" tetapi juga "bagaimana cara mengatakannya".
Di era digital, memang benar bahwa dalam berkomunikasi bukan sekadar apa dan bagaimana mengatakannya tetapi media mana yang digunakan. Begitu menentukan media yang digunakan adalah media sosial, dengan sendirinya bahasa yang digunakan adalah bahasa yang tidak baku, seperti banyak singkatan atau pemendekan, terjadi alih kode atau campur kode, dan sebagainya. Meskipun demikian, secara pragmasemantik banyak kosa kata yang memiliki daya sentuh, namun bila tidak disampaikan melalui media yang tepat, daya sentuh tidak akan sampai pada pembaca atau pendengar. Kosa kata atau frasa yang dapat memunculkan daya sentuh adalah kosa kata atau frasa yang berkaitan dengan hati atau perasaan yang dapat menimbulkan rasa empati atau simpati. Bahkan yang harus dipahami lagi adalah bahwa setiap orang memiliki kepekaan sendiri-sendiri terhadap setiap kejadian yang dihadapi. Dengan adanya Covid-I9 ini pun masih banyak yang tidak tersentuh rasa empatinya. Oleh karena itu, peneliti harus mampu memilih dan menentukan kosa kata atau frasa mana yang mampu menyentuh perasaan mitra tutur. Dengan demikian, ciri penanda pemakai media sosial perlu dilihat (a) siapa yang menggunakan, (b) apa yang sampaikan, (c) bagaimana cara menyampaikannya, (d) topik apa yang sedang dibicarakan, dsb.

Dengan demikian, tuturan yang sama tidak akan membawa dampak apa-apa jika yang menuturkan tidak memiliki kekhasan dalam komunikasi. Hal ini dapat terjadi karena pemahaman pembaca atau pendengar berbeda dengan yang dimaksud oleh penutur. Tuturan yang semula bermakna monointerpretable dapat menjadi multiinterpretable. Akibatnya, tuturan itu menimbulkan ketaksaan tafsir. Jika tidak berhatihati, ambiguitas yang banyak ditemukan dalam media massa, seperti surat kabar dan televisi, akan semakin banyak muncul di media sosial. Pesan di media sosial memiliki konvensi tersendiri sebagai suatu sistem tanda. Makna yang disampaikan tidak diutarakan sekadar melalui tuturan, tetapi juga melalui gambar atau bentuk visual dan yang memperkuat simbol atau citra yang ingin ditampilkan oleh pesan tersebut. Pesan-pesan tersebut bertujuan untuk mempengaruhi dan mengajak (Yusmawati, 2018). Sejalan dengan yang disampaikan oleh para ahli pragmatik ketika berkomunikasi, yang penting bukan apa yang disampaikan tetapi bagaimana cara menyampaikannya (Brown et al., 2013). Oleh karena itu, bahasa yang mampu mempersuasi pendengar atau pembaca adalah bahasa yang disampaikan agar mampu menyentuh perasaannya. Kadang-kadang, dalam media sosial dapat menimbulkan rasa lucu 
karena pemakai bahasa mampu membaca berbagai perasaan banyak orang yang sedang melakukan karantina wilayah.

Peran media sosial berbasis internet sangat besar pengaruhnya terhadap masyarakat dalam komunikasi. Pengaruh perubahan sosial terhadap perilaku masyarakat tidak dapat dihindari, seperti pola interaksi, aspek bahasa, gaya berpakaian, peningkatan cinta tanah air, dan lain-lain (Maksudi, 2018). Secara jujur, harus diakui bahwa peran media sosial di era global sangat berpengaruh dalam perubahan sosial yang terjadi di masyarakat (Nurrizka, 2016). Di akhir-akhir, media sosial telah menjadi pilar utama dalam penyampaian informasi. Media sosial dapat dipergunakan untuk berbagai keperluan, termasuk sosialisasi program pengendalian virus corona (Ita Suryani, 20I4).

Dari peran seperti itu, semula peneliti berpikir negatif, bahwa msyarakat Indonesia yang memiliki telepon genggam (HP) hanyalah untuk gagahgagahan dan konsumtif. Hampir setiap hari kemanapun membawa $H P$ padahal berbagai urusan belum tentu memerlukan $H P$. Namun, setelah peneliti mengidentifikasi berbagai dat, mengkategorikan, dan menginterpretasi, kemudian muncul pikiran lain. Dengan berbagai aplikasi yang ada di dalam $H P$, mereka dapat mengoperasikan berbagai macam keperluan yang dapat mempermudah, mempercepat, memperlancar berbagai informasi untuk sampai pada benak mereka, termasuk pemanfaatan media sosial untuk mengendalikan covid-I9.

Dari sekian banyak penggunaan bahasa dalam media sosial, dalam kaitannya dengan Covid-I9 adalah cenderung memberi kesadaran agar masyarakat mau menaati agar tidak terpapar virus corona, seperti selalu memakai masker, rajin mencuci tangan dengan sabun yang airnya mengalir, selalu menjaga jarak fisik dan jarak sosial, mengihindari kerumunan, dsb.

\section{Simpulan}

Berdasarkan hasil analisis data dan diskusi di atas dapat disimpulkan beberapa hal sebagai berikut. Pertama, fungsi bahasa di media sosial dalam kaitannya dengan sosialisasi Covid-I9 pada subfungsi menyuruh, mengajak atau mempengaruhi, menyindir, memotivasi dan mengkritik, dan mengucapkan terima kasih. Dari sekian banyak subfungsi, sebenarnya fungsi bahasa di media sosial pada dasarnya fungsi personal. Namun, jika dicermati lebih jauh, fungsi media sosial dalam menggunakan bahasa lebih banyak untuk mencari jati diri, mengekspresikan diri, mencari teman berdiskusi, kadang-kadang untuk "curhat" (curahan hati), mengeluh dsb.

Kedua, makna pragmatik di media sosial berkaitan dengan Covid-I9 kebanyakan adalah menasihati secara tidak langsung, membujuk, mengingatkan secara tidak langsung, menyindir secara halus, mengajak, mengeluh, dan memberi saran. Meskipun demikian, jika dicermati lebih jauh, bahasa dalam media sosial lebih banyak tidak menggunakan makna pragmatik, sebagian ungkapan dinyatakan secara berterus terang.

\section{Persantunan}

Penulis mengucapkan terima kasih kepada seluruh pihak yang telah berperan dalam membantu penelitian ini. Selanjutnya kepada tim editor Bahastra yang telah membantu publikasi artikel ilmiah ini.

\section{Daftar Pustaka}

Alfarizi, M. K. (2020). Berapa Jumlah Penduduk Indonesia 2020? Naik atau Turun?

Austin, J. L. (I962a). How to Do Things With Words. OXFORD AT THE CLARENDON PRESS.

Austin, J. L. (1962b). How to Do Thngs With Words. Oxford University Press, PRINTED IN GREAT BRITAIN.

Blount, B. G. (20I I). A History of Cognitive Anthropology. A Companion to Cognitive Anthropology, July 20II, 9-29. https://doi.org/I0.I002/978I44439493I.chI

Brown, G., Yule, G., Brown, G., \& Yule, G. (2013). Introduction: linguistic forms and functions. In Discourse Analysis. https://doi.org/I0.IOI7/cbo97805I I805226.00 3

Buana, D. R. (2020). Pnemonia Covid-I9. Diagnosis \& Penatalaksanaan di Indonesia.

Ita Suryani. (20I4). PENGARUH MEDIA SOSIAL TERHADAP PERUBAHAN SOSIAL MASYARAKAT DI INDONESIA. Jurnal Komunikasi, 8, no.2 Ap, I23-I38.

Kaburise, P. (2012). Recognising Speech Acts. Per Linguam, 28(I), 36-48. https://doi.org/I0.5785/28-I-I 18

Lukin, A., Moore, A., Herke, M., Wegener, R., \& Wu, C. (20II). Halliday's model of register revisited and explored. Linguistics and the Human Sciences, 4(2). https://doi.org/IO.I558/lhs.v4i2.I87

Maksudi, I. A. R. dan B. I. (20I8). PERAN MEDIA SOSIAL DALAM PENINGKATAN PARTISIPASI PEMILIH PEMULA DIKALANGAN PELAJAR DI KABUPATEN BOGOR. Sosiohumaniora - Jurnal Ilmu-Ilmu Sosial Dan Humaniora, Vol. 20, N, I54-I6I. 
Nurrizka, A. F. (2016). Peran Media Sosial di Era Globalisasi Pada Remaja di Surakarta Suatu Kajian Teoritis dan Praktis Terhadap Remaja dalam Perspektif Perubahan Sosial. Jurnal Analisa Sosiologi, 51 (28), 28-37.

Pertiwi, D. (20I8). STRATEGI KOMUNIKASI PERSUASIF DALAM MENINGKATKAN JUMLAH DEBITUR DI PT. BNI (PERSERO) TBK KANTOR CABANG PADANG. Jom Fisip, 5, I-I4.

Porayska-pomsta, K., Mellish, C., Pain, H., Eugenio, B. Di, \& Moore, J. D. (2000). Pragmatic Analysis of Teachers ' Language. Towards an Empirically Based Approach . Pain.

Searle. (1962). Speech Acts. Harfard: Harfard Publishers.

Watie, E. D. S. (2016). Komunikasi dan Media Sosial (Communications and Social Media). Jurnal The Messenger, 3(2), 69.

https://doi.org/I0.26623/themessenger.v3i2.270

Yusmawati. (2018). MAKNA AMBIGUITAS PESAN PEMBERDAYAAN MASYARAKAT (Studi Kasus: Kampanye Sosial "Ketimbang Ngemis" di Media Sosial). Lugas, 2.

Yusny, R. (2013). Appropriatizing Politeness Theory for Intercultural Communication in Elt. Jurnal Ilmiah Didaktika, I4(I), I76-I89.

https://doi.org/I0.22373/jid.vI4iI.496 
